MISES: Revista Interdisciplinar de Filosofia, Direito e Economia ISSN 2318-0811

Volume IV, Número 1 (Edição 7) Janeiro-Junho 2016: 263-281

\title{
Cervantes e a Teoria Econômica - Parte $\mathbf{I}^{*}$
}

\author{
Darío Fernández-Morera ${ }^{* *}$
}

Resumo: Questionando interpretações a respeito de Miguel de Cervantes como tendo sido um autor de caráter socialista com preocupações emancipatórias, o autor analisa a obra literária de Cervantes em seu contexto e identifica como apresenta simpatia para com aspectos importantes da economia de mercado, bem como critica posições coletivistas e redistribucionistas.

Palavras-Chave: Literatura. Teoria econômica. Economia de Mercado. Miguel de Cervantes.

\section{Cervantes and Economic Theory - Part I}

\begin{abstract}
Questioning interpretations about Miguel de Cervantes as having been an author of socialist character with emancipatory concerns, the author analyzes Cervantes's literary works in their context and identifies how they present sympathy towards important aspects of market economy, as well as criticisms of collectivist and redistributionist stances.
\end{abstract}

Keywords: Literature. Economic theory. Market economy. Miguel de Cervantes.

Classificação JEL: A12, B11.

\footnotetext{
* Publicado originalmente em: CANTOR, Paul \& COX, Stephen (Eds.). Literature and the Economics of Liberty: Spontaneous Order in Culture. Auburn, AL: Ludwig von Mises Institute, 2009. p. 99-165. A segunda parte deste artigo será publicada na próxima edição de MISES: Revista Interdisciplinar de Filosofia, Direito e Economia.

Traduzido do inglês para o português por Beatriz Caldas.

${ }^{*}$ Darío Fernández-Morera, Ph.D., é professor associado do Department of Spanish \& Portuguese da Northwestern University (Evanston, Illinois). Suas obras incluem os livros "American Academia and the Survival of Marxist Ideas" e "The Myth of the Andalusian Paradise: Muslims, Christians, and Jews under Islamic Rule in Medieval Spain".

E-mail: voltaire@northwestern.edu
} 


\section{I - INTRODUÇÃo}

Os críticos com frequência sujeitam um grande escritor a interpretações sofridas que refletem seus interesses, obsessões, inseguranças e necessidades de carreira. William Shakespeare (1564-1616) é um exemplo bem conhecido, com diretores teatrais que se abrem à feroz criatividade em seus textos, e produzem uma Iago fumante de charutos, uma Lady Macbeth compreensiva, uma versão lésbica de Sonho de uma Noite de Verão, uma versão feminista de $A$ megera domada, e uma versão pacifista de Henrique $V$ completa com soldados ingleses pisoteando a bandeira de São Jorge.

O destino de Miguel de Cervantes (15471616) iguala-se ao de Shakespeare. Em certa ocasião, Cervantes foi interpretado como defensor da Contra-Reforma e da expulsão dos muçulmanos que ainda permaneciam na Espanha, os mouros ${ }^{1}$. Mas, depois da Guerra Civil Espanhola, os exilados que ocupavam os departamentos de literatura de língua estrangeira fora de Espanha o transformaram em alguém com ideias parecidas às de um liberal da república espanhola². Os marxistas foram mais longe, interpretando-o como socialista ${ }^{3}$. Ao compartilhar muitas das premissas básicas dos marxistas, os acadêmicos de Estudos Culturais e Pós-coloniais transformaram Cervantes em uma réplica dos próprios professores, atribuindo-lhe, por vezes, um vocabulá-

1 Cf. LLOLIS, Cesare de. Cervantes: Reazionario. Roma: Fratelli Treves, 1924. As encenações da tragédia Numancia, de Cervantes, por exemplo, enfatizariam seu apelo ao patriotismo, nacionalismo, honra e o caráter marcial espanhol. Ofereço uma interpretação mais rica em nuanças em FERNÁNDEZ-MORERA, Darío. Cervantes and Islam: A Contemporary Analogy. In: REICHENBERGER, K. \& LAUER, R. A. (Eds.). Cervantes y su mundo III. Kassel: Reichenberger, 2005. p 123-157. Veja também FERNÁNDEZMORERA, Darío. The Myth of the Andalusian Paradise. Intercollegiate Review, Vol. 41, No. 2 (Fall 2006): 23-31.

${ }^{2}$ Cf. as obras posteriores de Américo Castro, por exemplo, e os seus discípulos.

${ }^{3}$ Veja, por exemplo, OSTERC, Ludovik. El pensamiento social y político del Quijote. México: Ediciones Andrea, 196). rio um tanto diferente, embora, acompanhado do polilogismo marxista ao qual ainda se prendem muitos termos marxistas respeitáveis, tais como "base material", "ideologia", "propriedade dos meios de produção", "alienação", "fetichismo", "sobredeterminação", "discursos sociais", "distribuição da riqueza", "superestrutura", "burguês", "cultura material", "classe", "condições de produção", "formações sociais" e "imperialismo". ${ }^{4}$ As críticas feministas, é claro, nos ofereceram uma Cervantes feminista. ${ }^{5}$ Alguns críticos católicos o leram, obviamente, como um católico e até mesmo um místico, embora um número maior de professores anticatólicos o tenham visto como um erasmiano, ou até mesmo como um autor anticatólico ${ }^{6}$. Mais recentemente, Cer-

\begin{abstract}
${ }^{4}$ Para um exemplo, consulte a crônica de consciente ousadia em <www.chronicle.com/weekly/v47/i21/21a01.htm>. Para o polilogismo marxista e outras premissas e vocabulário herdado pela pesquisa acadêmica contemporânea, veja FERNÁNDEZ-MORERA, Darío. American Academia and the Survival of Marxist Ideas. Westport, Conn.: Praeger, 1997; para polilogismo marxista em geral, veja MISES, Ludwig von. Theory and History. New Haven, Conn.: Yale University Press, 1957; reeditado em Auburn, Ala.: Ludwig von Mises Institute, 1985); MISES, Ludwig von. Human Action. Auburn, Ala.: Ludwig von Mises Institute, 1998. Para um exemplo do uso amplo contínuo de terminologia e premissas marxistas nos níveis mais altos das profissões vinculadas a línguas e literatura, veja o Discurso Presidencial de 1986 proferido por J. Hillis Miller da Modern Language Association em PMLA 102, n. 3 (May 1987): 281-91. Para um bom tratamento de Cervantes, do ponto de vista de premissas marxistas ("materialistas") de adeptos de "Estudos Culturais", veja JOHNSON, Carroll B. Cervantes and the Material World. Chicago: University of Illinois Press, 1999. O trabalho anterior de Johnson sobre a Idade de Ouro espanhola incluía as abordagens freudianas, quando o freudismo ainda estava na moda.
\end{abstract}

${ }^{5}$ A representante é EL SAFFAR, Ruth. Voces marginales y la visión del ser cervantino. Anthropos, Vol. 98-99 (1989): 52-62.

${ }^{6}$ Para o primeiro, veja MEREJKOWSKI, Dmitri de. Cervantes. Hispania (Paris), Vol. 4 (1921): 97-124; CHESTERTON, G. K. The Divine Parody of Don Quixote. Daily News (1901); reimpresso em COLLINS, Dorothy (Ed.). A Handful of Authors. New York \& London: Sheed e Ward, 1969. p 2427; AUDEN, W. H. The Ironic Hero: Some Reflections on Don Quixote. Horizon, Vol. 20 (1949): 86-94; reimpresso em NELSON Jr., Lowry (Ed.). Cervantes. Englewood, N. J.: Prentice-Hall, 1969. p. 73-81. Particularmente impressionante é RIELO, Fernando. Teoría del Quijote: Su mística hispánica. Madrid: Porrúa, 1982. Para o erasmianismo em Cervantes, veja entre outros, CASTRO, Américo. El pensamiento de Cervantes. Madrid: Hernando, 1925. O melhor trabalho geral 
vantes foi interpretado como homossexual e um teórico Queer avant la lettre ${ }^{7}$.

Inspirado nesses exemplos, e, em teoria, autorizado pela premissa pós-estruturalista, segundo a qual cada texto enfraquece seu próprio significado supostamente fixo, quero examinar Cervantes não tanto como um capitalista avant la lettre, mas como um escritor cujas obras apresentam situações, declarações e ideias que iluminam com simpatia aspectos importantes da economia de mercado ao oferecer material para uma crítica ao coletivismo, estatismo e redistribucionismo.

Esta abordagem parece aberta à objeção histórica. A palavra "capitalismo" ainda não era usada nos dias de Cervantes; ele não conhecia muitas das práticas que associamos ao capitalismo, e escreveu quase dois séculos antes de Adam Smith (1723-1790), o pensador que geralmente se considera o primeiro a apresentar uma base teórica para o capitalismo. Se Cervantes ignorava o capitalismo na teoria e na prática, como poderia ter algo a nos ensinar sobre o assunto?

A objeção ao olhar para Cervantes à luz da economia de livre-mercado é agravada pelo fato de que ele viveu e escreveu na Espanha católica. Como um bastião do mercantilismo europeu, a Espanha, via de regra,

sobre o erasmianismo em Espanha é BATAILLON, Marcel. Erasme et 1'Espagne. Paris: Droz, 1937, que foi por diversas vezes reeditado e traduzido. KAISER, Walter. Praisers of Folly. Cambridge, Mass.: Harvard University Press, 1963 é um posicionamento muito legível de Cervantes dentro da tradição erasmiana do Louvor à Loucura.

${ }^{7} \mathrm{O}$ escritor gay Fernando Arrabal, em Un esclavo llamado Cervantes (Madrid: Espasa Calpe, 1996), considera Cervantes bissexual, um marrano (de família judaica converso, convertida, uma ideia que Américo Castro, ele próprio de ascendência de converso, popularizou em estudos de Cervantes). Arrabal também afirma que Cervantes mentia a respeito de ser aleijado: ele nunca perdeu o uso da mão esquerda, como geralmente se acredita, no entanto, ele esteve prestes a tê-la cortada para castigá-lo por homossexualidade, mas escapou a tempo. A nova e monumental biografia documentada de Kryzstof Sliwa mostra que não há fundamento para a especulação (com origem no século $X X$, e não no século XVII) sobre a ascendência converso de Cervantes ou sobre sua homossexualidade: SLIWA, Kryzstof. Vida de Miguel de Cervantes Saavedra. Kassel: Reichenberger, 2005. não é associada ao desenvolvimento do capitalismo. Desde o famoso livro de Max Weber (1864-1920), A Ética Protestante e o Espírito do Capitalismo, é comum considerar o capitalismo como o desenvolvimento nos países protestantes do norte da Europa, especialmente a Grã-Bretanha e Holanda. Aqueles que adotam esse ponto de vista acham que o capitalismo deve ter sido teorizado a princípio no norte da Europa protestante e assim, fica de fora Adam Smith, o homem da Escócia8.

Na verdade, a tese de Weber distorce a nossa compreensão da história da teoria e prática econômica. Muitas das instituições e práticas distintas que associamos ao capitalismo foram desenvolvidas no mundo católico da Europa meridional. Por exemplo, a atividade bancária no sentido moderno e métodos de contabilidade surgiram pela primeira vez em cidades-estado da Itália católica, como Veneza, Gênova, Florença e Milão, durante o fim da Idade Média. E na época de Cervantes, a Espanha católica era uma das maiores potências econômicas da Europa. Essa situação lhe permitiu observar muita atividade econômica em primeira mão. Além disso, ao contrário da opinião popular, a teoria econômica não começou com Adam Smith, nem foi ele o primeiro a desenvolver uma explicação sobre o mercado livre. Como demonstraram os historiadores do pensamento econômico entre os quais H. M. Robertson (1905-1984), Murray Rothbard (1926-1995), Jesús Huerta de Soto, e Alejandro Chafuen, a visão tradicional do desenvolvimento da teoria econômica deve ser revista com o intuito de reconhecer as contribuições de uma série de pensadores antes de Adam Smith'.

\footnotetext{
${ }^{8}$ Da mesma forma, o direito internacional é associado por muitos aos protestantes do norte, como Hugo Grotius (15831645), e não aos primeiros fundadores católicos espanhóis, como Francisco de Vitoria e Domingo de Soto. 9 ROBERTSON, H. M. Aspects of the Rise of Economic
Individualism: A Criticism of Max Weber and His School.
Clifton, N.J.: Augustus M. Kelley, 1973; ROTHBARD,
Murray. Economic Thought Before Adam Smith: An
Austrian Perspective on the History of Economic Thought.
Vol. 1. Brookfield, Vt.: Edward Elgar, 1995; HUERTA DE
} 
De particular importância é a contribuição da chamada Escola de Salamanca, pensadores espanhóis do século XVI que anteciparam muitas das ideias básicas da economia moderna, de livre-mercado, incluindo a teoria do valor subjetivo, a lei das vantagens comparativas, a teoria da oferta e da procura, o entendimento da inflação como fenômeno monetário, e o problema da produtividade na teoria e na prática do socialismo. Esses católicos espanhóis tiveram uma compreensão mais sofisticada de mercado livre do que a de Smith. Portanto, um dos meus objetivos é chamar a atenção para esses pensadores e mostrar que Cervantes poderia ter sido exposto a toda uma gama de ideias econômicas importantes, algumas delas de apoio à liberdade econômica, algumas delas críticas do intervencionismo estatal. A situação histórica de Cervantes, na verdade, faz com que seja bastante plausível que em muitos de seus escritos ele possa estar comentando, entre outras coisas, as questões econômicas importantes que têm a ver com a liberdade socioeconômica e as tentativas do governo para restringi-la.

\section{II - Cervantes e a Escola Espanhola DE ECONOMIA}

Durante o reinado de Carlos V (15001558), o centro de gravidade econômica na Europa passou de cidades comerciais da Itália setentrional para a cidade portuária de Sevilha, devido ao gigantesco aporte de ouro das Américas. Durante esse período, também, o governo espanhol iniciou uma série de aven-

SOTO, Jesús. New Light on the Prehistory of the Theory of Banking and the School of Salamanca. Review of Austrian Economics, Vol. 9, No. 2 (1996): 59-81; CHAFUEN, Alejandro A. et al, Cristianismo y libertad. Buenos Aires: Fundación para el Avance de la Educación, 1984; CHAFUEN, Alejandro A. Christians for Freedom: Late Scholastic Economics. San Francisco: Ignatius, 1986. Para as cidades-estado italianas, consulte STARK, Rodney. The Victory of Reason: How Christianity Led to Freedom, Capitalism, and Western Success. New York: Random House, 2005. p. 84-117. turas de política externa que exigia vultosas quantias de receita. Os déficits orçamentários tornaram-se enormes e mais de uma vez o Estado declarou falência e negou suas dívidas ${ }^{10}$. Carlos V, a princípio e, mais tarde, seus sucessores usaram o sistema bancário sem escrúpulos e tributaram implacavelmente seus súditos com o intuito de obter a liquidez necessária para financiar gastos governamentais descontrolados ${ }^{11}$.

O enfoque espanhol em questões econômicas e a ostentação de um governo espanhol perdulário e ganancioso que suga a vida dos produtores - entre os quais os lojistas e outros empresários, artesãos, profissionais, criadores de ovinos, agricultores e membros da nobreza em atividade - e também, que, de outra forma, atrapalha o funcionamento de uma economia de mercado explica, em parte, a até então inédita concentração na Europa de mentes muito versadas sobre o tema da economia ${ }^{12}$. Entre outros estavam Domingo de Soto (1495-1560), Domingo de Báñez (15281604), Luis de Molina (1535-1600), Juan de Mariana (1535-1624), Martín de Azpilcueta (1493-1596), Francisco de Vitoria (1480-1546), e Tomás de Mercado (1500-1575), que são coletivamente conhecidos por várias denomi-

10 DAVIES, R. Trevor. The Golden Century of Spain. London: Macmillan, 1937; reeditado em Harper \& Row, 1961, p. 78 .

${ }^{11}$ HUERTA DE SOTO. New Light on the Prehistory of the Theory of Banking and the School of Salamanca.

${ }^{12}$ Muitos membros da nobreza inferior (hidalgos) tinham que trabalhar para viver ou morrer de fome. Veja VASSBERG, David A. Land and Society in Golden Age Spain. Cambridge, UK.: Cambridge University Press, 1984. p. 91. Geralmente se ignora que a nobreza, como a Igreja, estava sujeita a alguns tipos de impostos, como o alcabala e os millones. A nobreza não era uma classe homogênea nem monolítica. A classe média, tampouco. Evito o termo "burguesia", porque agrupa muitos indivíduos e atividades diferentes e, portanto, é inexata, e porque desumaniza as pessoas. Após o extermínio de dezenas de milhões de denominados "burgueses" sob regimes marxistas em todo o mundo, a utilização deste termo é mais do que ofensiva. O termo antiburguesia é tão hediondo quanto antissemitismo. Para os problemas de lógica do termo "burguesia", nunca sequer levados em conta pelo marxismo, veja MISES. Human Action e MISES. Theory and History, e também CROCE, Benedetto. My Philosophy. New York: Collier, 1962. 
nações, tais como Escolásticos Espanhóis, a Escola Espanhola de Economia, ou a Escola de Economia de Salamanca, muito embora alguns desses pensadores mais importantes não terem ensinado na Universidade de Salamanca.

Tal foi o caso, por exemplo, de Domingo de Soto, que lecionava na Universidade Complutense de Alcalá de Henares, cidade em que Cervantes parece ter nascido, conforme ele menciona em Don Quijote, e onde publicou seu romance pastoral La Galatea ${ }^{13}$. Em suas viagens de negócios a sua cidade natal, Cervantes poderia ter tido contato direto com o legado das ideias de livre-mercado que de Soto havia publicado e ensinado na geração antes da sua.

Além disso, se, como aventam alguns estudiosos, ele frequentou a escola jesuíta em Sevilha, rememorada por ele com carinho em sua Novela Exemplar, "O colóquio dos cães", poderia bem ter ouvido falar das contribuições à economia de livre-mercado, feitas por pensadores escolásticos como os jesuítas Luis de Molina e Juan de Mariana ${ }^{14}$. Na época, os pensadores jesuítas eram pioneiros na defesa da expansão do livre comércio, livre iniciativa e livre especulação. De acordo com H. M. Robertson, foram os jesuítas, e não os calvinistas, os precursores do espírito do capitalismo na Europa ${ }^{15}$. Mariana estabeleceu uma relação audaciosa entre a prosperidade e o interesse próprio e a atividade empresarial: "Existe algo mais tolo do que agir contra os nossos próprios interesses... com o intuito de servir aos interesses de outra pessoa?" Em palavras que remetem a Ludwig von Mises e Adam Smith, ele escreveu que "nada induz a ação mais do

\footnotetext{
13 A única outra candidata viável a ser a cidade natal de Cervantes é Alcázar de San Juan. Veja, entre outros, RUBIO ERGUIDO, Manuel. Desagravio a Miguel de Cervantes Saavedra. Alcázar de San Juan: Mata, 1978.

${ }^{14}$ Entre aqueles que pensavam que Cervantes tinha estudado com os jesuítas estão F. Rodríguez Marín e W. Krauss; veja CASTRO. El pensamiento, p. 280, 320, n. 133.

15 ROBERTSON. Aspects of the Rise of Economic Individualism.
}

que aquilo que é útil a alguém, seja esse alguém um príncipe ou um cidadão"16. Para ele, o comércio era necessário para o bem-estar de todos: "Se a troca de bens fosse abolida, a sociedade seria inviável e todos nós viveríamos em aflição e angústia." Também tratou do problema da escassez econômica e sua solução através do mercado: "A escassez pode ser superada por meio da troca mútua de [bens]". Mariana observou como a posse de coisas em comum como parte de seus votos de pobreza fazia os jesuítas antieconômicos: em uma declaração clássica sobre a razão pela qual o governo e, em geral, os bens de propriedade pública é ineficiente, ele escreveu: "Nós [Jesuítas] somos muito perdulários... Certamente, é natural que as pessoas gastem muito mais quando recebem as coisas de forma comunitária do que quando têm que obter as coisas por conta própria"17.

Se Cervantes alguma vez participou de algumas aulas na Universidade de Salamanca, como pensam outros estudiosos, poderia ter sido exposto às ideias de livre-mercado da Escola de Salamanca. Economistas como Rothbard, Huerta de Soto, e Chafuén traçaram a conexão direta entre esses pensadores da Idade de Ouro espanhola de Cervantes e a moderna teoria do capitalismo ${ }^{18}$. É difícil imaginar que Cervantes, tão interessado em tudo ao seu redor, incluindo economia, não teria tido contato com essas ideias ${ }^{19}$. O conhecimento do

\footnotetext{
${ }^{16}$ Para esta e as seguintes, veja MARIANA, Juan de. Del Rey y de la Institución Real in Biblioteca de Autores Españoles. Madrid: Ediciones Atlas, 1950, vol. 31, pp. 559ff.
}

17 MARIANA, Juan de. Discurso de las cosas de la Compañía, In: Biblioteca de Autores Españoles, vol. 31, p. 604 .

18 ROTHBARD. Economic Thought Before Adam Smith; HUERTA DE SOTO. New Light on the Prehistory of the Theory of Banking and the School of Salamanca; CHAFUEN et al., Cristianismo y libertad; CHAFUEN. Christians for Freedom.

19 Um recente estudo de numismática chega mesmo a considerar Don Quijote um dos "recursos numismáticos mais importantes" para o estudo deste tema na Idade de Ouro. Veja FIERO, David Brian. Don Quijote: A Numismatic and Economic Analysis. Literary Images of Coinage, Wealth and Poverty, em <www.lib.umi.com/dissertations/fullcit>. 
mundo que Cervantes tinha de seu tempo e sua curiosidade intelectual e leitura voraz são impressionantes. Don Quijote por si só constitui uma verdadeira enciclopédia de literatura e ideias do Renascimento e pré-Renascimento; uma das vozes autorais em Quijote alude a tal curiosidade intelectual e práticas de leitura voraz quando admite uma paixão pelo olhar a qualquer coisa impressa, incluindo papéis rasgados encontrados na rua ${ }^{20}$; e o fascínio de Dom Quixote pela palavra impressa fica evidente tanto em sua relação de caráter obsessivo com os livros e em seu vívido interesse no processo de produção do livro, mais claramente durante a sua visita à tipografia em Barcelona ${ }^{21}$.

A Escola Espanhola de economia era parte da cultura da época de Cervantes e, devido à sensibilidade de suas "antenas culturais", ele pode muito bem ter tido conhecimento de pelo menos algumas de suas ideias. Mas, mesmo que Cervantes nunca tenha se deparado com a economia dos Escolásticos Espanhóis, é provável que a sua atenção minuciosa a como e por que agem os homens, tão evidente em todas as suas obras, tenha facilitado seus insights praxiológicos sobre alguns fundamentos da economia de mercado. Além disso, seus anos na colmeia comercial de Sevilha, e suas experiências únicas dentro das entranhas da gananciosa "besta do governo", como funcionário encarregado de suprimentos para a Invencível Armada e mais tarde, como coletor de impostos, poderiam ter conquistado sua simpatia às dificuldades enfrentadas pelos produtores e lhe despertado a consciência dos problemas criados pelas po-

Este estudo, interessante por outros motivos, é seriamente prejudicado pela persistência de pressupostos e perspectivas materialistas (marxistas).

${ }^{20}$ CERVANTES, Miguel de. Don Quijote, pt. I, cap. ix. Cito Don Quijote por parte de capítulo e números. (N. do T.: Em tradução brasileira, NOUGUÉ, Carlos e SÁNCHEZ, José Luis, $\mathbf{O}$ engenhoso fidalgo D. Quixote da Mancha. Rio de Janeiro, São Paulo: Editora Record, 2005. Segunda parte, cap. ix, p. 106-107).

${ }^{21}$ CERVANTES. Don Quijote, pt. II, cap. 1xii. líticas governamentais equivocadas. E, como veremos, os próprios problemas de Cervantes como produtor de riqueza também podem ter contribuído para a sua conscientização das questões econômicas.

\section{III - A Defesa da Propriedade Privada em Cervantes}

A propriedade privada e sua proteção são fundamentais para uma economia de mercado. Os Escolásticos Espanhóis da época de Cervantes compreenderam este fato de forma clara e escreveram com profusão sobre o assunto. Domingo de Soto criticava a propriedade pública dos meios de produção. Argumentava que a abundância não era possível sob o regime de propriedade comum. Se, por um lado, a terra for de propriedade particular e a sua produção for compartilhada comunitariamente, essa injustiça criará problemas: "As recompensas pelo trabalho serão desiguais. Aqueles que possuem mais terras terão que trabalhar mais, porém os frutos de seu trabalho serão distribuídos a todos igualmente de acordo com a necessidade. Eles se ressentirão de receber menos apesar de trabalhar mais" 22 . Se a propriedade da terra e a fruição particular de produtos forem comuns "cada um terá a expectativa que o outro faça o trabalho... a distribuição de bens vai causar grande inveja". Se tanto a terra quanto a produção forem de propriedade comum, "cada trabalhador tentará apropriar-se de tantos bens quanto possível, e tendo em conta que os seres humanos desejam riquezas, todos vão se comportar da mesma forma. A paz, a tranquilidade e a amizade almejada pelos filósofos serão, assim, inevitavelmente subvertidas". De Soto percebeu a imoralidade da falta de proprie-

\footnotetext{
${ }^{22}$ Esta e as seguintes em SOTO, Domingo de. De Iuistitia et Iure. Madrid: IEP, 1968, livro IV, cap. 3, p. 105-06. Minhas citações dos Escolásticos Espanhóis reproduzem as traduções em CHAFUEN. Christians for Freedom.
} 
dade privada: "aqueles que nada possuem não podem ser liberais", e, portanto, a generosidade será sacrificada. Sem ter vivido sob regime socialista, de Soto previu os problemas das economias socialistas do século XX. A leitura de de Soto remete ao forte romance antissocialista do matemático e escritor russo Alexandre Zinoviev (1922-2006), The Radiant Future, no qual são apresentadas todas as consequências teóricas e, de forma mais chocante, as consequências morais de uma propriedade comum dos meios de produção permeando a vida cotidiana na Rússia Soviética ${ }^{23}$.

Tomás de Mercado também parecia estar falando contra o socialismo moderno, mas estava simplesmente fazendo afirmações teóricas derivadas de suas argutas observações da vida concreta na Espanha de seu tempo. Postulando o truísmo econômico moderno da oferta limitada de materiais, bens e serviços na vida real (o fato econômico de escassez), Mercado se dá conta de como a propriedade privada reduz a escassez ao levar a uma maior produtividade, enquanto a propriedade comum contribui para a escassez ao levar a menor produtividade:

Podemos ver que floresce a propriedade privada, enquanto a propriedade do poder executivo e legislativo do município sofre de cuidados inadequados e gestão ainda pior... Se o amor universal não induz as pessoas a cuidar das coisas, o interesse da vontade privada o fará. Assim, os bens de propriedade privada se multiplicarão. Se tivessem continuado em posse comum, o oposto seria verdade ${ }^{24}$.

Semelhante a de Soto, Tomás de Mercado viu claramente os problemas não apenas das economias completamente socializadas, mas até mesmo das empresas do governo. Pode-se contrastar seus pontos de vista com

\footnotetext{
${ }^{23}$ ZINOVIEV, Alexander. The Radiant Future. New York: Random House, 1980. Examinei este romance em relação à teoria marxista em minha obra American Academia.

${ }^{24}$ MERCADO, Tomás de. Summa de Tratos y Contratos. Sevilha, 1571, livro II, cap. ii, pp. 18-19.
}

os de Vladimir Lenin (1870-1924), por exemplo, que, inspirado pela "economia" de Karl Marx (1818-1883) viu o Correio como modelo de como administrar empresas e o país ${ }^{25}$. De acordo com Mercado, a propriedade (pública) comum é má política porque as pessoas adoram a maioria das coisas que lhes pertencem. Se eu amo a Deus, ele é o meu Deus, Criador e Salvador que eu amo. Se eu amo a quem me criou, é meu pai a quem amo. Se um pai ama os filhos, é porque são dele. Se uma esposa ama o marido é porque ele pertence a ela e vice-versa... E se eu amar um amigo é meu amigo ou meu pai ou meu vizinho. Se eu desejar o bem comum, é em benefício de minha religião ou de meu país ou de minha nação. $\mathrm{O}$ amor sempre envolve a palavra meu e o conceito de propriedade é fundamental para a natureza e essência do amor.

Da mesma forma, Francisco de Vitoria considerava a propriedade privada necessária para a força universal da generosidade e, portanto, para a moralidade: "A esmola deve ser dada a partir de bens privados, e não a partir dos bens comuns". ${ }^{26}$

25 Para uma exposição e crítica de pontos de vista surpreendentemente primitivos de Lenin sobre economia, veja MISES. Theory and History, p. 328; e MISES, Ludwig von. Socialism: An Economic and Sociological Analysis. Indianapolis: Liberty Fund, 1981, p. 188-189. Para os problemas fundamentais da "economia" de Marx e sua inviabilidade teórica, veja BÖHM-BAWERK, Eugen von. Unresolved Contradiction in the Marxian Economic System, reimpresso em Shorter Classics of Böhm-Bawerk. South Holland, Ill.: Libertarian Press, 1962, vol. I, p. 199-302.; BÖHMBAWERK, Eugen von. The Exploitation Theory and Its Common Offshoot, em Capital and Interest. South Holland, Ill.: Libertarian Press, 1959, p 422-32.; MISES. Human Action; SOWELL, Thomas. Marxism: Philosophy and Economics. New York: William Morrow, 1985; GORDON, David. Critics of Marxism. New Brunswick, N.J.: Transaction, 1986. Estes livros são discussões puramente teóricas que não abordam as aplicações práticas fracassadas de ideias econômicas de Marx em muitos países diferentes, feitas por muitas e diversas pessoas brilhantes e sob condições que variam de sociedades industriais (por exemplo, Alemanha) a sociedades de camponeses (por exemplo, China e Camboja) e tudo entre uma coisa e outra (Rússia, Polônia, e assim por diante).

${ }^{26}$ VITORIA, Francisco de. De Iustitia. Madrid: Publicaciones de la Asociación Francisco de Vitoria, 1934, vols. I-II, cap. 66 , art. 2, p. 324 . Vitoria não diz, mas fica implícito em sua afirmação que tirar dinheiro de pessoas à força (digamos, através de impostos) para dar a outros (redistribuição) 
Como autor, Cervantes teve motivos profissionais para apoiar a propriedade privada, conforme mostra a história da publicação de Don Quijote. Um dos fatos cruciais na escrita e estrutura de Don Quijote (a Parte I surgiu em 1608; a Parte II, em 1615) foi a apropriação de suas principais personagens, Dom Quixote e Sancho, por outro escritor que usava o pseudônimo de Alonso Fernández de Avellaneda, que em 1614 publicou em Tordesillas a Segunda Parte de las hazanas de don Quijote de la Mancha. A Parte I do Don Quijote de Cervantes é quase uma colagem de livros pré-existentes, que não só influenciam a escrita, mas também fazem parte do texto na forma de citações e paródias, e com o qual o livro sustenta uma conversa em andamento. A Parte II acrescenta uma complicação a essa relação já complicada com outros textos, introduzindo uma Parte I publicada dentro da ficção da Parte II. Assim, a Parte II remete não só aos livros a que estavam relacionados à Parte $\mathrm{I}$, mas também a si mesma, na forma da Parte I. Aconteceu, no entanto, que, durante a escrita de Cervantes da Parte II, surgiu o livro de Avellaneda. Cervantes ficou furioso. Mudou o texto da Parte II, a fim de fazer várias referências desfavoráveis a Avellaneda e a seus "falsos" Dom Quixote e Sancho. De propósito, alterou o percurso de Dom Quixote, enviando-o a Barcelona, que não tinha sido mencionado na Parte I, em vez de mandá-lo para Zaragoza, um destino que havia sido anunciado na Parte I e tinha sido usado por Avellaneda. Vingou-se de Avellaneda apropriando-se de uma das per-

impede as pessoas de terem a chance de dar o seu próprio dinheiro a partir de vontade própria e, portanto, impede as pessoas de serem de fato liberais, hospitaleiras e generosas. Este é um argumento puramente moral que nem sequer leva em conta as objeções práticas ou utilitárias para redistribuição feitas por estudiosos como Mises e Friedrich A. Hayek (18991992), e que não são mencionadas na crítica moral clássica de JOUVENEL, Bertrand de. The Ethics of Redistribution. Indianapolis: Liberty Press, 1990. Veja MISES. Human Action; MISES. Socialism; HAYEK, F. A. The Fatal Conceit: The Errors of Socialism. Chicago: University of Chicago Press, 1988. Apenas Hoppe se aproxima: veja HOPPE, Hans-Hermann. A Theory of Socialism and Capitalism: Economics, Politics, and Ethics. Boston: Kluwer, 1989, p. 178-210. sonagens do livro de Avellaneda, Dom Álvaro Tarfe. Fez Tarfe assinar um documento em que esta personagem de Avellaneda declara, atesta e jura a falsidade de Dom Quixote e Sancho no livro de Avellaneda e a veracidade do Dom Quixote e Sancho a quem Tarfe acabou de conhecer na Parte II do Don Quijote de Cervantes (no capítulo lxxii, em que Dom Quixote denomina Avellaneda "usurpador do meu nome" duas vezes no mesmo parágrafo). E, no processo, Cervantes demonstrou que era um escritor superior ao fazer uso muito mais interessante de Tarfe do que havia feito o autor da personagem.

Cervantes chegou ao auge de seu ataque implacável ao ladrão ao escrever um Prólogo para a Parte II, que gira em torno do roubo da criação imortal de Cervantes por Avellaneda (embora Cervantes confesse que sua fúria foi também motivada pelo fato de Avellaneda tê-lo xingado de aleijado e velho). Neste prólogo, uma obra-prima de vitupérios literários sutis e nem tão sutis, Cervantes destrói Avellaneda.

Assim, a complexa relação da Parte II com os livros é ainda mais complicada pelo combate contra um escritor que havia roubado a produção intelectual de Cervantes. A Parte II interage com os livros incluídos na Parte I, com a Parte I, e com o livro de Avellaneda. Portanto, a maior complexidade da Parte II, a sua própria estrutura, está articulada à questão dos direitos de propriedade: a abertura característica dos livros de cavalaria, que Don Quijote emprega ao extremo, usando o leitor como participante na criação da obra, Cervantes decide encerrar, como resultado do plágio de Avellaneda ${ }^{27}$. Esta sanha visceral contra alguém que violou a integridade da criação de Cervantes anula todos os ataques insanos contra a propriedade feitos por Dom Quixote, bem como o seu famoso discurso

27 FERNÁNDEZ-MORERA, Darío. Cervantes and the Aesthetics of Reception. Comparative Literature Studies, Vol. 18 (1981): 405-19; reimpresso em PERSON, James Person (Ed.)., Literature Criticism: from 1400-1800. Detroit: Gale, 1994, vol. 23. 
Idade de Ouro no romance, contra a propriedade privada.

No final de Don Quijote, a voz autoral de Cide Hamete Benengeli, o narrador mais aparente no livro, reafirma a intenção de Cervantes de proteger de uma vez por toda a sua propriedade intelectual:

E disse o mais prudente Cide Hamete à sua pena:

Aqui, minha pena, você descansará, pendurada neste armário por este fio de cobre. Bem afiada ou mal apontada, aqui você viverá longos tempos, a não ser que os historiadores presunçosos e indignos a tomem para profaná-la. Mas antes de tocá-la, advirta-lhes em termos tão fortes quanto conseguir:

Cuidado, cuidado, mesquinhos patifes todos,

Não posso ser tocada por ninguém:

Este empreendimento, meu valoroso rei,

Mantém-se só para mim.

Dom Quixote nasceu só para mim, e eu para ele. Ele sabia como agir, e eu sabia como escrever. Só nós dois somos como um só, apesar do escriba fictício natural de Tordesilhas que ousou, e pode ousar novamente, com sua tosca e mal aparada pena de avestruz, escrever as aventuras de meu valoroso cavaleiro. Este não é um fardo para seus ombros, não é assunto para sua musa ligada à geada; e se você, por acaso, chegar a conhecê-lo, avise-lhe que deixe os ossos cansados e embolorados de Dom Quixote descansando no túmulo, e não tente, contra todos os cânones da morte, levá-lo para o Velho Castelo, obrigando-o a deixar o túmulo onde ele de fato e de verdade jaz estendido por completo, impotente para uma terceira expedição e nova incursão. Certamente suas duas, que agradaram e contaram com a aprovação de todas as pessoas que sabiam sobre elas, tanto aqui como no exterior, são suficientes para fazer uma paródia de todas as inumeráveis excursões empreendidas por todos os incontáveis cavaleiros andantes. Assim, você cumprirá com sua profissão de fé cristã, oferecendo bom conselho a quem lhe de- seja o mal, e terei orgulho de ser o primeiro autor que jamais gostou de testemunhar o efeito completo de sua escrita. Pois o meu único objetivo é despertar o desprezo dos homens para as histórias falsas e absurdas da cavalaria andante, cujo prestígio foi abalado por este conto do meu verdadeiro Dom Quixote, e que, sem dúvida, em breve desmoronará em ruínas. Vale ${ }^{28}$.

Neste discurso, "Cide Hamete" suspende a pena como um cavaleiro dependura a espada, que na tradição de cavalaria poderia ser usada, como a pena de Cide Hamete, somente pelo "escolhido", ou melhor, cavaleiro; e esta alocução à pena, que subitamente metamorfoseia-se em um discurso da própria pena, é quase uma conjuração para fazer quaisquer autores futuros semelhantes a Avellaneda nunca mais tentarem roubar Dom Quixote.

Portanto, o destino final da personagem principal de Cervantes retorna ao problema dos direitos de propriedade. Pois, a fim de impossibilitar a qualquer outra pessoa mais uma vez roubar Dom Quixote, o escritor Cervantes mata sua criação. Então Dom Quixote, de fato, morre em defesa dos direitos de propriedade privada de Cervantes ${ }^{29}$.

28 CERVANTES, Miguel de. Don Quixote. Trad. Walter Starkie. New York: Signet, 1964. p. 1049-1050. Caso contrário, conforme indicado aqui, todas as traduções são minhas.

29 Estes direitos, então, tornam-se inquestionáveis quando sua violação acontece para afetar Cervantes, o autor real, de carne e osso do livro Don Quijote. Lembremo-nos de críticos literários desconstrutivistas como Jacques Derrida (1930-2004), que em seus escritos acadêmicos ou "teóricos" rejeitam a existência de autores reais na literatura, mas, com determinação, recorrem aos meios legais quando pensam que seus próprios direitos de propriedade da vida real estão ameaçados. Nem esses críticos que negam o autor e preferem falar, digamos, da "voz lírica," e não da voz do autor, jamais transferem para outros seus próprios direitos autorais. Para proteção feroz de seus direitos de propriedade por Derrida como autor, veja WOLIN, Richard (Ed.). The Heidegger Controversy. Cambridge, Mass.: MIT Press, 1993, p. ix-x. Os comentários demolidores de Wolin resumem minha questão: "Para começar, há as ironias a respeito do envolvimento de Derrida em uma disputa sobre as prerrogativas de 'autoria'. Quem, afinal, fez mais para pôr em causa nosso legado de concepção de autoridade autoral como um todo de que Jacques Derrida? Mas, neste caso [proibição de Derrida ver reproduzido no livro de Wolin seu artigo defendendo 
A consciência autoral de Cervantes é notável, mesmo em uma ocasião, o Renascimento, quando os escritores e os artistas estavam rompendo com o relativo anonimato habitual entre os produtores da Idade Média ${ }^{30}$. É verdade que na Espanha identificam-se instâncias de prévia consciência de autoria individual. Um exemplo é o Infante Don Juan Manuel (1282-1348). Ao escrever em 1330, inclui-se em suas obras de forma notória e demonstra orgulho de sua autoria e preocupação com o destino de seus trabalhos e com a qualidade de suas futuras reproduções ${ }^{31}$. O grande Arcipreste de Hita (1283-1350), também, demonstra consciência de sua singularidade como autor $^{32}$. No entanto, nada se compara ao canto lírico de Cervantes sobre si próprio e seus poderes criativos em alguns dos tercetos no capítulo IV de seu Viaje del Parnaso, que contém alguns dos seus versos mais sugestivos e pungentes, e onde o self, o orgulhoso Eu da Renascença torna-se motivo recorrente:

Yo corté con mi ingenio aquel vestido con que al mundo la hermosa Galatea salió para librarse del olvido.

(Adaptei-me com minha engenhosidade às vestes

Heidegger contra ataques por ter favorecido o NacionalSocialismo] invocou os direitos de autor na forma mais convencional e, somos tentados a dizer, na forma mais "précrítica". Será que o próprio Derrida é o único para quem ainda se aplica a noção de prerrogativa autoral irretocável"?

${ }^{30}$ FERNÁNDEZ-MORERA, Darío. 'Cervantes': Theory and Practice of the Modern Novel. CIEFL Bulletin, Vol. 15, No. 2 (Dec 2005) e Vol. 16, No. 1 (Jun 2006): 49-65.

${ }^{31}$ A primeira frase do seu trabalho mais duradouro, El conde Lucanor, anuncia com orgulho que o livro foi feito por Dom Juan, filho do príncipe Dom Manuel. Por suas preocupações sobre a transmissão correta de suas obras e sua propensão para incluir a si próprio em seus escritos, veja BLECUA, José Manuel. Don Juan Manuel: El conde Lucanor. Madrid: Castalia, 1969. p. 16, 45.

32 O Arcipreste, também escrevendo na década de 1330, destaca na introdução de seu Libro de Buen Amor que o que escreve não é só um novo livro (este nuevo libro), mas também o seu livro e de mais ninguém. Veja a repetição do possessivos mi e suyo no título, "Libro de Buen Amor, Oración qu'el Açipreste fizo à Dios, quando començó este libro suyo", e mais tarde na introdução (por ende comencé mi libro en el nobre de Dios). com as quais a bela Galatea saiu para o mundo para livrar-se do esquecimento).

Yo con estilo en parte razonable he compuesto Comedias que en su tiempo tuvieron de lo grave y de lo afable.

(Eu, com estilo próprio, compus Comédias que em seu tempo Eram não só graves mas também leves).

Yo he dado en Don Quijote pasatiempo al pecho melancólico y mohino en cualquiera sazón, en todo tiempo.

(Em Don Quijote ofereci entretenimento ao melancólico e ao triste em qualquer tempo ou estação do ano).

Yo he abierto en mis Novelas un camino por do la lengua castellana puede mostrar con propiedad desatino ${ }^{33}$.

(Com minhas Novelas abri um trajeto através do qual a língua castelhana pode mostrar com propriedade a loucura dos homens).

O caso Avellaneda mostra como Cervantes na qualidade de "produtor de um bem" foi "fortemente afetado pela existência de concorrência", como registrou Carl Menger (1840-1921) em sua obra clássica sobre os fundamentos da economia ${ }^{34}$. Toda a direção

${ }^{33}$ Ele contém este magnífico, tocante terceto:

$\mathrm{Y}$ en Dulces varias rimas se llevaron mis esperanzas los ligeros vientos que en ellos y en la arena se sembraron.

Esta consciência de seu gênio literário ecoa na grande peça teatral de Cervantes Pedro de Urdemalas, no louvor entoado à versátil criatividade de Pedro de Urdemalas por outras personagens e pelo próprio Pedro em versos que rescendem àqueles na Viaje del Parnaso:

Bien Logrado iré del mundo cuando Dios me lleve de él, pues podré decir que en él un Proteo fui segundo. (Jornada III)

${ }^{34}$ MENGER, Carl. Principles of Economics. Grove City, 
e estrutura do maior romance de Cervantes foram alteradas por um livro de outro escritor, em um caso exemplar de um produtor em resposta à concorrência. Porque, como lamenta o professor marxista-feminista-desconstrutivista no romance Nice Work de David Lodge, um escritor profissional em uma economia de mercado é um empresário da mente. "Inventa um produto que os consumidores não sabiam que queriam até que passasse a existir". Fabrica seu produto "com a ajuda de investidores de capital de risco conhecidos como editores". E, em seguida, vende o seu produto, "concorrendo com os fabricantes de produtos ligeiramente diferenciados da mesma espécie", ou seja, outros escritores ${ }^{35}$.

Infelizmente para Cervantes, como produtor de item intelectual de consumo, no século XVII só havia proteção limitada dos direitos à propriedade, em especial, da propriedade intelectual. Além disso, esses direitos não tinham proteção internacional. A Escola Espanhola de economia foi uma exceção em sua forte defesa dos direitos à propriedade, mas sua influência sobre a política pública era praticamente inexistente por causa da ganância do governo espanhol.

Assim, autores como Cervantes, e os empresários que imprimiram seus livros, estavam sujeitos a ver os produtos de sua lavra intelectual e de seu trabalho copiados quase que imediatamente por outra editora, ou roubado por outro autor. A única maneira de tentar evitar que isso acontecesse era obter do Estado (o rei) uma autorização (o privilegio, ou direito de publicação, mas, literalmente, um "privilégio" concedido pelo Estado e não um direito incontestável de produtor e de

Penn.: Libertarian Press, 1994, p. 224. Esta é uma tradução de James Dingwall e Bert F. Hoselitz do trabalho de Menger de 1871, com uma valiosa introdução de F. A. Hayek escrita para a reedição do livro de Menger pela London School of Economics.

${ }^{35}$ Esta personagem não acredita em personagem de ficção, leal como é ao desconstrutivismo e à teoria pós-estruturalista. Então, ela não acreditaria em si própria, pode-se supor. Ela se autodenomina uma "materialista semiótica". Veja LODGE, David. Nice Work. New York: Penguin, 1989, p. 21. proprietário), de modo que durante certo número de anos, e dentro de determinada área geográfica, ninguém mais teria permissão legal para imprimir o trabalho. No entanto, a aplicação deste direito não era constante nem completa, e, claro, para além da área geográfica presumivelmente "garantida", os livros estavam sujeitos à pirataria. Dentro de algumas semanas após a publicação de Don Quijote, três edições piratas apareceram em Portugal. Por causa do domínio dos Habsburgos, a Espanha ainda estava dividida em vários reinos antigos, os privilegios concedidos, por exemplo, em Castela, não eram necessariamente reconhecidos, digamos, nas Astúrias. Além disso, nada evitava que a personagem de um autor fosse usada por outro escritor. A situação é diferente hoje, quando os direitos à propriedade incluem a prevenção da pirataria das próprias personagens literárias. Testemunho disso, por exemplo, é a ação judicial movida pela autora inglesa J. K. Rowling contra o autor e os editores de uma série russa de livros que muito vagamente imita seus romances de Harry Potter e que apresenta uma versão feminina da personagem principal dessa autora.

A impotência de Cervantes em evitar que outro escritor roubasse Dom Quixote e Sancho ilustra não apenas a precariedade institucional, mas também a vulnerabilidade filosófica dos direitos à propriedade na Espanha de seu tempo. Vasta extensão de terras de pastagem e de exploração agrícola era "propriedade pública" de variadas formas e usos desconcertantes, tais como terras conhecidas como baldíos, terras de propriedade comum, de propriedade comunitária, terras da coroa, propriedade municipal, e a prática de presura $^{36}$. Naturalmente, nem todos recebiam

$36 \mathrm{Ou}$ os direitos dos invasores de terras. Veja NIETO, Alejandro. Bienes comunales. Madrid: Revista de Derecho Privado, 1964, p. 124-32; e PÉREZ DE URBEL, Fray Justo. La reconquista española y la repoblación del país. Zaragoza: CSIC, 1951, p. 127-162. Pode-se suspeitar que o direito de presura teria um impacto sobre a mentalidade dos pobres espanhóis que se deparavam com vastas áreas de terras sem uso durante a Conquista da América. A invasão de terras 
tratamento igual. Aqueles ligações com o governo, tais como funcionários municipais e o senhor do lugar, eram mais beneficiados, recebendo uma fatia maior do uso dessas terras "publicas" ${ }^{37}$. Existiam todos os tipos de outros problemas e complicações, típicos do que as economias modernas designam "o problema dos bens comuns", oriundos da falta de direitos de propriedade instituídos e limites claros de propriedade, e que têm influência sobre questões ambientais ${ }^{38}$.

As declarações bem conhecidas em favor da liberdade em todas as obras de Cervantes estão ligadas à sua defesa dos direitos de propriedade e à sua crítica temática da monarquia absoluta e dos burocratas do governo da Espanha. Como propõe John Locke (16321704), as funções de propriedade como instrumento contra o poder absoluto do Estado (no tempo de Locke e de Cervantes, contra o poder absoluto do soberano) porque limita o poder do Estado (do soberano) e liberta os súditos da "obrigação de obedecer aos decretos que punham em risco a sua propriedade" ${ }^{\prime \prime 2}$. E, como propunha Locke, também, a propriedade de alguém é a extensão de sua propriedade sobre si mesmo. Não se pode deixar de trazer à baila esse ponto de vista quando se lê em Don Quijote $^{40}$ o lamento de Maese Pedro sobre

desempenhou um papel, também, na colonização do Oeste americano pelo homem branco.

37 DOMÍNGUEZ ORTÍZ, Antonio. The Golden Age of Spain, 1516-1659. New York: Basic Books, 1971, p. 157.

38 ROTHBARD, Murray. Man, Economy, and State. Auburn, Ala.: Ludwig von Mises Institute, 1993, p. 828-829; HOPPE. A Theory of Socialism and Capitalism, p.188210; ANDERSON, Terry \& LEAL, Donald R. Free Market Environmentalism. San Francisco: Pacific Research Institute, 1991, p. 3, 7, 20-34, 61-81, 122-125, 147-150, 165-167; SELDON, Arthur. Capitalism. Oxford: Basil Blackwell, 1990, p. 86, 126, 129-33, 237-38, 327; e SOTO, Hernando de. The Other Path: The Invisible Revolution in the Third World. New York: Harper \& Row, 1989.

\footnotetext{
${ }^{39}$ Para esta e seguintes, veja RICHARDS, Judith ; MULLIGAN, Lotte \& GRAHAM, John K. 'Property' and 'People': Political Usages of Locke and Some Contemporaries, Journal of the History of Ideas, Vol. 42 (Jan-Mar 1981): 29-51.

${ }^{40}$ Don Quijote, pt. II, cap. xxvi.
}

a destruição de sua propriedade, os bonecos: "cúyos eran sus cuerpos sino míos?" (cujos corpos eram de quem, se não meus?). Depois, o destruidor da propriedade, Dom Quixote, reembolsa Pedro por todos os danos, como faz mais tarde no caso da aventura do Barco Encantado ${ }^{41}$.

Pode-se dizer, então, que a força dos direitos à propriedade em um determinado momento e lugar é uma medida da força da liberdade política naquele tempo e lugar. Se o produto intelectual ou do trabalho (o Quijote na época de Cervantes) puder ser tomado por outros (Avellaneda na época de Cervantes) sem sua autorização, então, fica inexoravelmente limitada a própria liberdade. A relação entre os direitos de propriedade e a liberdade torna-se ainda mais clara ao lembrar que Locke acreditava que propriedade não era apenas a propriedade que um sujeito possui, mas também o próprio corpo do sujeito, que também é propriedade do sujeito. Uma pessoa possui o próprio corpo, e considerando que a propriedade adquirida não é mais do que uma extensão do próprio corpo, o respeito pelos direitos de propriedade é, portanto, essencial para a própria propriedade do próprio corpo e, portanto, à própria liberdade. $\mathrm{O}$ Estado (ou o soberano) não tem mais direito a tomar a propriedade de um sujeito sem o seu consentimento de que pode tomar o seu corpo e, portanto, a sua liberdade sem o seu consentimento: ou, de forma mais clara, o Estado (o soberano) não pode tomar a liberdade de um sujeito, tout court, sem o seu consentimento. A propriedade privada é, portanto, a liberdade.

\section{IV - A Crítica de Cervantes ao Estado Redistribuidor}

A compreensão que Cervantes tinha de mercado pode ser mais bem entendida em

\footnotetext{
${ }^{41}$ Ibid., cap. xxix.
} 
conjunto com sua crítica ficcional do Estado em uma de suas Novelas Exemplares, "Rinconete e Cortadillo". Ao chegar a Sevilha, encontram-se os dois meninos, Rinconete e Cortadillo, e são forçados a participar de uma quadrilha bem organizada de ladrões, achacadores e outros tipos variados de patifes comandados por um homem grotesco, embora estranhamente paternal, chamado Monipodio. Os estudiosos tradicionalmente veem Monipodio e seu grupo como muitas coisas, como uma sátira à Igreja ou crime organizado, mas, tendo em vista a adesão ao estatismo, comum entre muitos acadêmicos, talvez não seja surpreendente que não o tenham visto como uma sátira e paródia às atividades e estruturas governamentais. E, ainda assim, depois de ter sido membro da burocracia governamental, Cervantes tinha uma perspectiva única sobre o funcionamento interno do Estado redistributivo, que, na melhor das hipóteses, toma do produtivo e redistribui ao menos produtivo ou improdutivo (como se prega no ensino parasitário de Marx: "De cada um segundo sua capacidade, a cada um segundo sua necessidade"), enquanto no processo de alimentação de uma vasta engrenagem de burocratas que são essenciais para o processo de redistribuição e que, portanto, têm uma participação não apenas na manutenção das máquinas de redistribuição, mas também na sua contínua expansão ${ }^{42}$. Cervantes sabia de primeira mão da necessidade desesperada de um governo para arrecadar receitas, a sua engenhosidade e crueldade na obtenção dessa renda, e os danos que tal ganância causa às pessoas produtivas na sociedade.

Conforme aponta Charles Adams, a tributação onerosa foi, provavelmente, a causa mais decisiva do declínio da Idade de Ouro da Espanha de Cervantes ${ }^{43}$. Por sua vez, em

42 MISES, Ludwig von. Bureaucracy. Spring Mills, Penn.: Libertarian Press, 1983; e DE JOUVENEL. Ethics of Redistribution.

43 Veja "The Collapse of the Hercules of Europe" na obraprima reveladora de ADAMS, Charles. For Good and Evil: The Impact of Taxes on the Course of Civilization. New grande parte, as consequências de envolvimentos estrangeiros e guerras eram o que desfalcava o tesouro espanhol e estimulava a ganância do governo pela receita. $\mathrm{O}$ imposto sobre o valor agregado, ou a alcabala, lamentado por Cortadillo no romance de Cervantes, foi particularmente prejudicial à economia, como sempre é esse tipo de imposto. Durante algum tempo Cervantes foi um alcabalero, um coletor desse imposto. Embora seja uma formidável máquina de arrecadar receitas, reduz o incentivo à produção, pois reduz os lucros e, além disso, encarece cada produto para os cidadãos. À medida que cada produtor sucessivo na fabricação e linha comercial aumenta o preço para compensar as despesas crescentes criadas pelo imposto sobre valor agregado, o custo de produção se eleva - e o preço final dos itens também sobe para os cidadãos que os consomem, afetando mais pesadamente àqueles com menos recursos ${ }^{44}$. Em Espanha, "os mesmos materiais, à medida que mudavam de mãos no decorrer do comércio e da indústria, pagavam o imposto de $10 \%$ muitas vezes, e, assim, deixavam os produtores castelhanos em desanimadora desvantagem quando comparados aos seus concorrentes estrangeiros" ${ }^{\prime \prime 5}$.

Os muçulmanos inventaram o imposto sobre valor agregado, que denominaram alcabala e o trouxeram quando invadiram a Península Ibérica em 711 A.D. Em Espanha, ficou conhecido pelo seu nome árabe e foi adotado por monarcas cristãos, que valorizaram a sua eficácia como fonte de receita. O governo de Carlos V contou fortemente com esse imposto. Percebendo seus efeitos perniciosos para o comércio e padrões de vida, no entanto, a rainha Isabel em seu testamento de 1504 recomen-

York: Madison Books, 1993, p. 185-198.

${ }^{44}$ Pode-se perceber esses efeitos ainda hoje no trabalho na Europa, onde até mesmo uma taxa de imposto de valor agregado mais baixo do que a da Idade de Ouro de Espanha faz o custo de vida mais elevado do que nos Estados Unidos da América e mais baixa a competitividade empresarial de forma geral.

${ }^{45}$ DAVIES. The Golden Century of Spain, p. 79. 
dou a abolição da alcabala. O Cardeal Francisco Jiménez de Cisneros (1436-1517), ministro de Carlos V, tentou dar-lhe um fim. Todavia, como no caso do Imposto de Renda dos EUA de hoje, o Estado tinha se acostumado, como um viciado em drogas, à grande receita gerada pela alcabala. Era "o mais lucrativo dos impostos... daí a tenacidade com que muitas gerações de reis castelhanos se agarraram a esta desastrosa importação" ${ }^{\prime 6}$. Também era desejável porque era inevitável para a maioria dos cidadãos, incluindo a nobreza (sobre os quais muitos historiadores erroneamente atribuem a isenção de todos os impostos) ${ }^{47}$. Os únicos que não eram diretamente afetados eram os muito pobres, que comiam pão e trigo importados do exterior e, portanto, não estavam sujeitos a alcabala. Portanto, este imposto foi expandido para incluir a cadeia de produção de alimentos, e suas taxas foram aumentadas.

A alcabala não era suficiente para as necessidades insaciáveis do Estado. A Igreja foi listada na busca de receitas, e indulgências do papa foram empurradas para a população, de modo que parte da renda que gerassem iria para os cofres reais (isto é um fator negligenciado no episódio do bulero no romance picaresco do século XVI Lazarillo de Tormes) ${ }^{48}$. Um imposto sobre o rendimento pessoal, chamado servicio, foi imposto aos plebeus, sendo isentos o clero e a nobreza. Outro imposto chamado millones foi imposto aos produtores agrícolas - não somente aos camponeses, mas também aos membros mais baixos da nobreza, que "tinham que trabalhar com o suor de seu rosto para não morrer de fome", pois, ao contrário do que normalmente se pensa, nem todos os nobres em Espanha eram ociosos, e ao contrário do que sugerem as categorias marxistas reducionistas, a nobreza não

\footnotetext{
${ }^{46}$ Idem. Ibidem.

${ }^{47}$ Os cadastros de contribuintes de Extremadura, por exemplo, incluem a nata da nobreza local. Veja VASSBERG, David A. Land and Society in Golden Age Castile. Cambridge, UK.: Cambridge University Press, 1984, p. 222.

${ }^{48}$ DAVIES. The Golden Century of Spain, p. 80.
}

era um grupo homogêneo ${ }^{49}$. Havia outros impostos e outros encargos também ${ }^{50}$.

Essa carga tributária, acrescida à necessidade de receita, criou todos os tipos de práticas de corrupção. Por exemplo, os conselhos de muitas cidades, relutantes em impor novos impostos diretos sobre a população, já sobrecarregada, recorria ao expediente de explorar os vários tipos de propriedade municipal disponíveis para eles... alugavam pastagens comuns a quem oferecesse a melhor oferta para ará-las, vendiam florestas de propriedade comum para extração de lenha, e especulavam com o recurso de celeiros públicos ${ }^{51}$.

Qualquer pessoa que conheça as administrações municipais e estaduais, e os procedimentos de concessionárias de serviços nos Estados Unidos da América, reconhecerão este desespero governamental para a obtenção de receitas de toda forma possível e sub-reptícia - tal como imposto de renda estadual, imposto de fundo de concessionárias, impostos municipais, impostos ambientais, impostos sobre serviços, impostos de recuperação de custos regulatórios, impostos universais de fundo de serviço, impostos especiais sobre o consumo, impostos 911, taxas de adesivos de estacionamento público na cidade, taxas urbanas de licença para cães, loterias, venda de espaço público para publicidade, e até mesmo os impostos locais sobre impostos ${ }^{52}$.

A alcabala desencorajava a criação de empresas industriais e comerciais, e, portanto, levou à estagnação na criação de novos postos de trabalho e, consequentemente, ao desemprego. Por que estabelecer um comércio e começar um empreendimento se a alta tributação destitui ambos de lucro? Isso, e

\footnotetext{
${ }^{49}$ VASSBERG. Land and Society in Golden Age Castile, p. 91. Os millones também tributavam a igreja.

${ }^{50}$ Idem. Ibidem, p. $225 \mathrm{ff}$.

${ }^{51}$ Idem. Ibidem, p. 224-25.

52 Em Evanston, Illinois, até há poucos anos, a cidade acrescentava o total das despesas do agregado familiar com, digamos, eletricidade, mais os impostos e taxas habituais, e em seguida tributava esse total, que já incluía os impostos.
} 
não apenas o propalado "orgulho espanhol" ou o sentido equivocado de honra explica por que tantos espanhóis escolhiam ficar ociosos: "Qualquer pobre diabo", explica o narrador espanhol em Lazarillo de Tormes, "morreria de fome antes de estabelecer um comércio [e pagar impostos, poder-se-ia acrescentar, que faria do estabelecimento de um comércio um prejuízo se alguém considerasse o esforço e os riscos envolvidos e as recompensas que se poderiam obter]. "Um intelectual moderno ressalta que" a indústria espanhola era estrangulada pelo sistema de tributação mais pesado e complicado que loucura humana pode conceber" ${ }^{\prime \prime}$.

As mercadorias estrangeiras, mais baratas porque não estavam sujeitas à alcabala, eram contrabandeadas para a Espanha para quebrar as limitações e as tarifas de importação, e tinham preços mais baixos que as mercadorias espanholas nos mercados locais. Assim, o ouro e a prata evadiam-se do país tão rápido quanto chegavam da América, e não só porque o governo os usava para pagar empréstimos estrangeiros, mas também porque os importadores os usavam para pagar mercadorias estrangeiras, e porque os espanhóis em geral relutavam em investir na própria Espanha, tendo em conta a situação econômica hostil aos empreendimentos.

Considerando que as antigas imunidades e a prática alfandegária dos antigos reinos espanhóis dificultavam muito a tributação para as guerras externas do governo, Carlos V tinha que tomar Castela como sua base de tributação. Em Castela, a tributação exigia a aprovação das Cortes, um órgão de representação análogo ao Parlamento inglês ou aos Estados Gerais francês. Mas, na verdade, por volta do século XVI, as Cortes castelhanas normalmente atendiam aos desejos do rei. Para os contribuintes, no entanto, o custo iria muito além disso.

\footnotetext{
53 DAVIES. The Golden Century of Spain. Citado em ADAMS. For Good and Evil: The Impact of Taxes on the Course of Civilization, p. 196.
}

Em 1520, antes de Carlos V ter consolidado seu governo como rei, uma revolta dos contribuintes pedindo verdadeira representação e prestação de contas das Cortes castelhanas se transformou em uma revolta social e política feia, a chamada revolta dos Comuneros. Os atos de violência cometidos pelos contribuintes enfurecidos fizeram parecer muito pequena a rebelião dos contribuintes norte-americanos em 1776. Em um deles, os amotinados mataram um membro da Corte, ignorando o seu pedido para receber os últimos rituais antes de morrer. Carlos V derrotou os rebeldes com dificuldade e brutalidade. Mas a revolta mostrou ao Imperador os limites do que os cidadãos aceitariam. Assim, em vez de confiar exclusivamente em novos impostos, ele recorreu a uma aplicação mais rigorosa dos impostos existentes e a um uso corrupto do sistema bancário em que os banqueiros participavam de boa vontade - um exemplo precoce de conluio entre o governo e setores influentes do mundo dos negócios que ilustra como tal combinação solapa a economia de mercado ${ }^{54}$.

A maioria dos contribuintes que fugiam da espoliação do governo foi para a América. "Os galeões partiram no dia 28 do mês passado", escreve um observador francês contemporâneo: "Estou certo de que, além das pessoas que embarcaram por razões comerciais, mais de 6.000 espanhóis transferiram-se para a América pela simples razão de que não conseguem viver em Espanha" 55 . O declínio causado pelo êxodo foi a razão pela qual o chanceler alemão Otto von Bismarck (1815-1898) não queria colônias para a Alemanha: ele usou o exemplo da Espanha para ilustrar como a fuga de sua população mais produtiva podia atingir a nação ${ }^{56}$. Esta

\footnotetext{
${ }^{54}$ HUERTA DE SOTO. New Light on the Prehistory of the Theory of Banking and the School of Salamanca, p. $60 \mathrm{ff}$. Huerta de Soto mostra a cumplicidade entre os banqueiros e Carlos V em práticas fraudulentas.

55 DAVIES, Trevor. Spain in Decline: 1621-1700. London: Macmillan, 1957, p. 159.

${ }^{56}$ Ele, claro, usou a expressão "melhor sangue". Veja ADAMS. For Good and Evil: The Impact of Taxes on the Course of Civilization, p. 189.
} 
razão mais importante tem sido encoberta ou mencionada apenas en passant pelos historiadores da Espanha, a maioria deles estatistas, que, ao invés disso, preferem atribuir a queda à expulsão dos muçulmanos, ou dos judeus.

A dimensão do governo espanhol desenvolveu-se da necessidade de criar burocracia para lidar com o recolhimento, administração e redistribuição da renda, e também com as aventuras externas do governo, exército e marinha. O governo tornou-se o maior empregador na Espanha. Os contribuintes acotovelavam-se pelos empregos públicos de prestação de serviços à disposição, que eram isentos de impostos e, como sempre acontece com o setor público, em qualquer tempo ou lugar, não geravam receitas - só podiam distribuí-las ${ }^{57}$. Cervantes e outros escritores contemporâneos da Idade de Ouro criaram um tema literário a partir dessa busca desesperada de emprego público ${ }^{58}$. Enquanto o governo crescia como empregador, o setor privado encolhia. Na burocracia "Existem mil funcionários", escreve um contemporâneo, "em que 40 seriam suficientes se fossem mantidos no local de trabalho; os outros restantes poderiam ser alocados na realização de algum trabalho útil" ${ }^{\prime 9}$. Qualquer pessoa conhecedora de excesso de empregos e falta de eficiência das burocracias governamentais, em qualquer tempo e lugar, reconhecerá a situação.

\footnotetext{
${ }^{57}$ Para a inerente falta de produtividade do setor público veja ROTHBARD. Man, Economy, and State, p. 791-807. Isto é verdade para o setor público como um todo econômico, mas também dos funcionários públicos individuais: burocratas do governo não pagam impostos; consomem os lucros dos impostos. Se um cidadão particular ganhar $\$ 10.000$ de renda, paga $\$ 2.000$ em impostos, o ganho do burocrata também no valor de \$10.000 não desconta de fato os \$2000 em impostos; o que se supõe que ele faça é apenas uma contabilidade fictícia. Na verdade, ele faz aquisição de uma renda de $\$ 8000$ e não paga imposto algum. (Idem. Ibidem, p. 791)

58 Assim, na Novela Exemplar de Cervantes, El licenciado Vidriera, a personagem principal empreende um esforço mal sucedido para conseguir emprego na burocracia (das Cortes reais) do governo.

${ }^{59}$ ADAMS. For Good and Evil: The Impact of Taxes on the Course of Civilization, p. 189.
}

É verdade que alguns historiadores indicam um curto período de prosperidade após o início do reinado de Carlos $\mathrm{V}$ e o atribuem ao aumento de preços, que, presumivelmente, estimulava a produção de bens ${ }^{60}$. A partir da perspectiva da teoria econômica moderna, no entanto, essa prosperidade não poderia ser legítima, mas sim um boom artificial criado pelas pressões inflacionárias que se originavam no enorme déficit do orçamento do Estado, a chegada de ouro da América, as exigências da guerra, e as despesas da conquista, colonização e defesa da América - um boom artificial que distorceu o funcionamento do mercado e que, ao ser acrescentado à pesada tributação acabou levando à situação que os economistas da Escola Austríaca denominam "depressão inflacionária" ${ }^{61}$.

A Escola Espanhola de economia estava ciente desses problemas. Apesar de Domingo de Soto admitir que certa tributação é necessária para financiar as necessidades essenciais do governo, tais como a defesa nacional, o sistema judiciário, e assim por diante, advertiu que "Grandes perigos para a república emergiam de exaustão financeira, a população sofre privações e é muito oprimida por aumentos diários de impostos" ${ }^{\prime 2}$. Diego de Saavedra Fajardo (1584-1648), que não era um escolástico, mas sim um escritor leigo como Cervantes, advertiu que "o poder é louco e tem de ser contido pela prudência econômica. Sem prudência, os impérios declinam. O Império Romano caiu devido a gastos excessivos dos imperadores, que consumiram todos os seus tesouros" ${ }^{\prime 63}$. Mariana condenou a belicosidade

60 DAVIES. The Golden Century of Spain, p. 66-70; BENNASSAR, Bartolomé. La España del Siglo de Oro. Barcelona: Editorial Crítica, 1983, p. 209.

\footnotetext{
${ }^{61}$ Aplico à Espanha as ideias sobre os chamados ciclos de negócios e depressões econômicas dos economistas da Escola Austríaca como Rothbard em Man, Economy, and State e Mises em Human Action.

${ }^{62}$ De Iustitia et Iure, livro III, qu. VI, art. VII, fol. 98.

${ }^{63}$ SAAVEDRA FAJARDO, Diego de. Idea de un Príncipe Político-Cristiano. In: Biblioteca de Autores Españoles. Madrid: Editions Atlas, 1947, vol. 25, p. 191.
} 
dos tiranos e sua inclinação para encetar uma guerra depois de outra e procurar "os ricos e os bons" para obter a sua receita ${ }^{64}$. Pedro Fernández de Navarrete, Capelão e Secretário de Carlos V, escreveu que o principal problema da Espanha era a emigração provocada como consequência dos altos impostos que as pessoas tinham de pagar para financiar os gastos públicos e que, sem atingir esse objetivo, forçava o imperador a reduzir os gastos ${ }^{65}$. Seguindo o raciocínio de um economista moderno, Navarrete rejeitou a ideia de que a abundância de dinheiro em uma nação é sinal de prosperidade, e, em vez disso, definiu riqueza como produtividade. "A origem da pobreza," acrescentou, "são os altos impostos. Sempre com medo de coletores [os agricultores] preferem abandonar as suas terras para evitar esses dissabores. Como afirmava o rei Teodorico [um rei visigodo], o único país agradável é aquele em que nenhum homem tem medo dos coletores de impostos" 66 . Ele também entendia o problema governamental moderno de matar com altas taxas de impostos a galinha dos ovos de ouro: "aquele que impõe altos impostos recebe de muito poucos", e uma vez que o número de pessoas produtivas consequentemente diminui "enfraquecem as costas daqueles poucos que ficam para sustentar o fardo" 67 .

Tendo sido coletor de impostos uma vez na vida, Cervantes conhecia ambos os lados do processo de tributação. Por um lado, o governo procura desesperadamente maneiras de extrair mais e mais riqueza dos cidadãos produtivos com o intuito apenas de se manter em funcionamento. Por outro lado, os cidadãos produtivos tentam desesperadamente manter os resultados de sua produtividade. Cervantes teria conhecido as revoltas e fuga dos con-

\footnotetext{
${ }^{64}$ MARIANA. Del Rey, p. 469.

${ }^{65}$ FERNÁNDEZ DE NAVARRETE, Pedro. Conservación de Monarquías. Madrid, 1619, citado em CHAFUEN. Christians for Freedom, p. 66, n. 19.

${ }^{66}$ CHAFUEN. Christians for Freedom, p. 67.

${ }^{67}$ Idem. Ibidem.
}

tribuintes espanhóis e testemunhado os engenhosos esforços dos contribuintes para esconder os frutos da sua produtividade, ou seja, suas rendas - modos engenhosos de evasão fiscal que, por sua vez, levou o governo a reprimir com mais regulamentos para impedir a fraude, dificultando ainda mais a geração de empregos, e assim por diante, em uma espiral bem descrita pela economia de mercado dos dias atuais ${ }^{68}$. "O contribuinte [espanhol]", escreve Trevor Davies, o intelectual da Idade de Ouro, "sobrecarregado pelos tributos, foi envolvido em uma rede de regulamentos para evitar a evasão... Foi assim mutilado a cada passo pela influência mortal da acumulação anômala e incoerente de extorsões" ${ }^{\prime \prime}$.

A crítica de Cervantes acerca do Estado distributivo em "Rinconete e Cortadillo" começa com uma paródia bem-humorada de tentativas do governo para controlar o empreendedorismo e do furto do governo sobre os produtores, à medida que Rinconete e Cortadillo aprendem para sua surpresa que o seu "trabalho", roubar, é regulamentado e tributado pelo "governo" de Monipodio. A recusa de pagar ao governo pelo direito ao trabalho, ou seja, a recusa de obter uma "licença" para exercer o seu "comércio", e qualquer tentativa de evitar o pagamento de impostos sobre os seus lucros será severamente punido: “isso vai lhe custar caro" (les costará caro), ouvem os dois meninos. Além disso, têm de passar pela aduana (alfândega) do Sr. Monipodio.

A resposta de Cortadillo à ameaça do governo é uma declaração libertária clássica sobre o direito ao trabalho que qualquer produtor tem sem ter que pagar impostos de produção ou comprar uma "licença" para trabalhar: Yo pensé que el hurtar era oficio libre, horro de pecho y alcabala, y que si se paga, es por junto,

\footnotetext{
${ }^{68}$ Veja MISES. Human Action; MISES, Ludwig von. Middleof-the-Road Policy Leads to Socialism, em Planning for Freedom. Spring Mills, Penn.: Libertarian Press, 1980, p. 1835.; e MISES. Bureaucracy.

69 DAVIES. The Golden Century of Spain, citado em ADAMS. For Good and Evil: The Impact of Taxes on the Course of Civilization, p. 196.
} 
dando por fiadores a la garganta y a las espaldas" ("Pensei que o roubo fosse uma iniciativa livre sobre a qual não incorresse nem encargos nem a alcabala, e que se fosse exigido pagamento, fosse em uma única parcela, com o pescoço ou as costas em segurança"). Ele se pergunta se os ladrões nessa parte do país têm que pagar "encargos" e ouve como resposta que os ladrões devem, no mínimo, "cadastrar" junto a autoridade do governo, ou seja, junto a Monipodio, quem é o "pai, mentor, e protetor" dos ladrões. Uma vez que o governo espanhol na verdade não taxava os ladrões, Cervantes deve estar zombando de um sistema descontrolado, um sistema que ele achou mais seguro criticar por meio da apresentação bem-humorada de uma quadrilha de ladrões que agem como um governo respeitável.

Na obra "Rinconete e Cortadillo" de Cervantes, o governo, na verdade, é uma corja de ladrões. Quando, em um trecho do romance, o dinheiro retirado dos cidadãos de Sevilha vitimados pelos ladrões não pode ser contabilizado na sociedade de Monipodio, o executivo-chefe do governo (Monipodio) fica furioso não por ter tomado dinheiro de quem fez por merecê-lo, mas por ter transgredido as regras do governo. Assim, a "tributação" de seu governo, desde o início fundamentada na imoralidade (tomar à força dos inocentes e produtivos) é duplamente imoral porque não consegue sequer manter as suas próprias regras de roubo. Irritado com esse dinheiro roubado que parece ter sido roubado mais adiante ou furtado ao quadrado, explode a raiva de Monipodio:

"!Nadie se burle con quebrantar la más mínima cosa de nuestra orden, que le costará la vida! Manifiéstese la cica, y si se encubre por no pagar los derechos, yo le daré enteramente lo que le toca, y pondré lo demás de mi casa, porque en todas maneras ha de ir contento el alguacil" ("Que ninguém brinque livre e solto com a mínima regulamentação de nossa ordem, pois isso lhe custará a vida. A bolsa deve ser entregue, e se estiver sendo escondida para escapar do tributo devido, darei a ele [fiscal] sua parte inte- gral e pagarei o saldo do meu próprio bolso, pois, haja o que houver, o policial deve ficar satisfeito").

Um detalhe colateral contribui para a crítica ao governo: o funcionário municipal, o alguacil sevilhano (fiscal), está em conluio com os bandidos. Mais uma vez, qualquer pessoa conhecedora de muitas administrações de governos municipais e até mesmo estaduais nos EUA hoje reconhecerá a situação em Sevilha durante a Idade de Ouro ${ }^{70}$.

Atrás da resposta de Cortadillo reside toda uma construção teórica da economia. De acordo com a teoria econômica, o governo precisa de receitas para todos os tipos de ações redistributivas e de exercício de poder, mais frequentemente a guerra ${ }^{71}$. Até mesmo o economista Joseph A. Schumpeter, que, particularmente, não é defensor convicto do livre-mercado, escreveu que o Estado está vivendo de uma renda que estava sendo produzido na esfera privada para fins particulares e teve que ser desviada desses propósitos por força política. A teoria que interpreta os impostos com base na analogia com quotas de clube ou contratação dos serviços de, digamos, um médico, só prova como esta parte das ciências sociais está distante dos hábitos intelectuais científicos ${ }^{72}$.

Assim, o Estado constantemente procura novas fontes de receita, com a única ressalva que não tribute tanto o produtivo que de70 Os jornalistas de Chicago como John Kass ganharam a
vida fazendo reportagens sobre a corrupção do governo em
nível municipal e estadual. Veja, por exemplo, as colunas
regulares de Kass durante o ano de 2003, no Chicago Tribune
sobre o prefeito de Chicago Richard Daley e sobre George
Ryan, ex-governador de Illinois (preso por corrupção). Entre
suas muitas colunas pode-se citar KASS, John. U.S. attorney's
independence pays dividends. Chicago Tribune, Dec 21,
2003.

71 ROTHBARD, Murray. The Ethics of Liberty. Atlantic Highlands, N.J.: Humanities Press, 1982; NOCK, Albert J. Our Enemy, the State. Delevan, N.Y: Hallberg, 1983; JASAY, Antony. The State. London: Basil Blackwell, 1985; e HOPPE. A Theory of Socialism and Capitalism.

72 SCHUMPETER, Joseph A. Capitalism Socialism, and Democracy. New York: Harper \& Row, 1942, p. 198, 198, n. 11. 
sapareça o incentivo para produzir. No processo de roubar os ovos de ouro, não se deve atrapalhar a galinha dos ovos a continuar a por os ovos ou nem mesmo deixá-la propensa a número menor de ovos. Portanto, a fim de aumentar a receita passível para gastos, e insatisfeito com a tributação direta, tributação de vendas, ou com os meios mais sutis de tributação como a impressão de dinheiro (e, portanto, desvalorização gradual da moeda e inflação), o governo cria um monopólio sobre o direito de produzir e passa a vender esse direito. Em seguida, o produtor deve obter uma autorização ("licença") por parte do governo, se quiser produzir. Por um lado, os indivíduos têm o direito de trabalhar e produzir em sua profissão escolhida sem permissão nem interferência do governo. Por outro lado, o governo precisa desesperadamente de receita. Os dois lados não podem coexistir. Mas, o Estado, por ser mais poderoso por conta de seu usual monopólio de força, via de regra, ganha. A necessidade desesperada de receitas geralmente se disfarça como um esforço para garantir a qualidade e segurança do que é produzido. As áreas que necessitam de permissão são gradualmente estendidas, de modo que, no fim, até mesmo os barbeiros e cabeleireiros são obrigados a obter licenças. A teoria do mercado livre contraria o argumento da segurança, ressaltando que o medo de perder clientes e ir à falência junto a selos de qualidade de iniciativa privada, como os Consumer Reports e aprovações UL, conseguem resolver a situação tão bem, ou melhor, sem a interferência do governo.
As expansões governamentais do monopólio de licenciamento acabam entrando em áreas de ação desagradáveis não fora da esfera de gangsters como Monipodio. Tomemos, por exemplo, jogos de azar. Do ponto de vista moral, o jogo cai tradicionalmente dentro de uma área cinza de pecaminosidade. Mas foi transformado em atividade ilegal pela ganância de receitas do governo. Assim, por exemplo, em muitas áreas dos Estados Unidos da América, muitas formas de jogos de azar (apostas a dinheiro) são legalmente proibidas. Por outro lado, o jogo é permitido por lei, desde que o jogo seja "permitido" pelo governo em cassinos, ou em instituições de propriedade do governo, como em loterias estaduais. Como Monipodio, o governo transforma uma atividade presumivelmente indesejável, proibida pelo governo, em uma atividade que não apenas é aceita, mas também é entusiasticamente promovida e anunciada pelo governo como propícia para o bem-estar das pessoas, como ocorre com as loterias estaduais, em que são ignorados os danos que a compulsão do jogo pode causar a cidadãos que agem livremente, desde que o jogo seja sancionado pelo governo e, portanto, desde que os jogos de azar tragam mais receitas para os cofres do Estado. Em algumas partes da Europa, a prostituição é tratada de forma semelhante. Então, o que costumavam ser atividades promovidas e supervisionadas por gangsters tornam-se atividades patrocinadas e supervisionadas pelo governo. cos 